University of Nebraska - Lincoln

DigitalCommons@University of Nebraska - Lincoln

\title{
A Simple Roller-Mill Grinding Procedure for Plant and Soil Samples
}

\author{
S. L. Arnold \\ University of Nebraska-Lincoln, sarnold1@unl.edu \\ James Schepers \\ United States Department of Agriculture, Agricultural Research Service, james.schepers@gmail.com
}

Follow this and additional works at: https://digitalcommons.unl.edu/usdaarsfacpub

Part of the Agricultural Science Commons

Arnold, S. L. and Schepers, James, "A Simple Roller-Mill Grinding Procedure for Plant and Soil Samples" (2004). Publications from USDA-ARS / UNL Faculty. 588.

https://digitalcommons.unl.edu/usdaarsfacpub/588

This Article is brought to you for free and open access by the U.S. Department of Agriculture: Agricultural Research Service, Lincoln, Nebraska at DigitalCommons@University of Nebraska - Lincoln. It has been accepted for inclusion in Publications from USDA-ARS / UNL Faculty by an authorized administrator of DigitalCommons@University of Nebraska - Lincoln. 


\title{
A Simple Roller-Mill Grinding Procedure for Plant and Soil Samples ${ }^{\#}$
}

\author{
S. L. Arnold* and J. S. Schepers \\ USDA-ARS-SWCRU, University of Nebraska, Lincoln, \\ Nebraska, USA
}

\begin{abstract}
Obtaining finely ground, homogeneous plant and soil samples for chemical analysis without cross contamination is a major concern when using direct combustion procedures for determination of total nitrogen $(\mathrm{N})$, total carbon $(\mathrm{C})$, and isotope-ratio analysis. A rollermilling device, using square glass bottles instead of round grinding bottles, was evaluated. Rotation of the square bottles on the roller mechanism increased the milling action by the stainless steel rods inside the bottles. The roller-milling device with square grinding bottles resulted in a sample with smaller particles $(99.2 \%<100$ mesh) than with a ball-milling device $(83 \%<100$ mesh). The roller-mill
\end{abstract}

\footnotetext{
\#This article is a joint contribution of the US Department of Agriculture and University of Nebraska, Lincoln. Published as Journal Series Number 13961. *Correspondence: S. L. Arnold, USDA-ARS-SWCRU, 120 Keim Hall, University of Nebraska, Lincoln, NE 68583-0934, USA; E-mail: sarnold1@ unl.edu.
} 
provided acceptable results (soil and plant samples ranging from $1.6-43.8 \% \mathrm{C}, 0.5-2.3 \% \mathrm{~N}$, and $0.3777-1.038$ atom $\%{ }^{15} \mathrm{~N}$ (isotopic ratio analysis) had coefficients of variation ranging from $0.44-1.78$, to $0.97-1.60$, and $0.09-1.43$, respectively) while providing an economical approach to grinding large numbers of samples to achieve finely ground, homogeneous samples with minimal labor and equipment costs.

\section{INTRODUCTION}

Adoption of direct combustion techniques for determination of total $\mathrm{N}$ to replace the Kjeldahl procedure ${ }^{[1,2]}$ and total $\mathrm{C}$ determination to replace wet oxidation methods ${ }^{[3]}$ has brought about a need for modification of sample processing procedures. Sample size, using traditional wet oxidation digestion procedures for $\mathrm{C}$ and $\mathrm{N}$ analyses, is much larger (100-500 mg) than for dry combustion procedures $(5-35 \mathrm{mg})$. This dramatic reduction in sample size brings increased concerns over analytical precision, and sample homogeneity. Modern digital balances make it possible to routinely obtain accurate and reproducible sample weights, but obtaining a representative sample can be a major problem unless samples are finely ground and well mixed.

Past research with Dumas-type combustion procedures has involved various mechanical grinding devices to prepare the samples. Plant and soil samples processed through a Wiley ${ }^{\mathrm{a}}$ mill or soil grinder (10 or 20 mesh sieve) can be difficult to mix.

This makes it hard to obtain a small, but representative sample, especially for heterogeneous materials (e.g., soil and corn stover) or others that are difficult to grind (e.g., oat and wheat straw). Mortar and pestle or mechanical ball milling is frequently considered the ultimate approach to sample processing. Mechanical milling devices either tend to be quite slow if many samples are processed at one time, or they will only accommodate a few samples if processing time is rapid. Many situations require mechanical milling to obtain the desired analytical precision and accuracy. As such, the user must compromise between the additional time and labor required to operate the much more aggressive oscillating ball

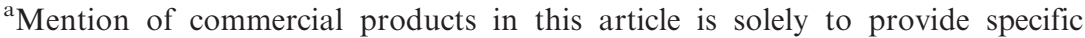
information for the reader. It does not constitute endorsement by the USDA's Agricultural Research Service or University of Nebraska's Agricultural Research Division over other products that may be suitable.
} 
mills compared to the longer time (12-16h) required for the more docile roller-type mills.

Commercial applications or situations where a large number of samples must be processed, analysts frequently opt for roller milling because of the reduced cost of sample preparation and reduced chance of cross-contamination. The time requirement for processing remains the primary obstacle for roller-mill operations. Typical roller-mill devices use round bottles with metal rods inside to pulverize the material as the bottles roll on a moving conveyor belt or between rotating rods. Smith and Myung ${ }^{[4]}$ glued several rods to the inside of round grinding bottles to increase the pounding action of the tumbling rods. Occasional cleats attached to a conveyer belt mechanism have also been used to increase the hammering action of the grinding rods inside the bottles. ${ }^{[5]}$

The intent of grinding soil and plant materials is to provide a homogeneous sample that results in acceptable precision after weighing and chemical analysis. It should be noted that the accuracy of analytical results can be influenced by grinding, especially for certain nutrient extraction processes ${ }^{[6]}$ or when abrasion of the grinding vessel contaminates the sample. ${ }^{[7]}$

The objectives of the research are to assess a modification to the simple roller-mill procedure for processing plant and soil samples described by Smith and Myung ${ }^{[4]}$ and compare analytical results using several grinding/ milling devices.

\section{MATERIALS AND METHODS}

A roller mill (Fig. 1) consisting of six (1.5 m long) solid-steel rods covered with rubber to collectively serve as rollers ( 80 bottle sample capacity) was used in this study. This apparatus was constructed in the early 1960's and previously was used to mill Devarda's alloy for steam-distillation procedures.

Each of the parallel $3.5-\mathrm{cm}$ diameter rollers (including the rubber covering) was supported on each end with a bearing assembly that maintained a 3.2-cm spacing between rollers (6.7-cm center-to-center). Twelve-toothed sprockets (5-cm diameter) were placed on one end of each steel rod as it protruded through the bearing mechanism. All rollers were rotated in the same direction by running the drive chain over the topside of each drive sprocket. A gear-reduction motor was used to drive the rollers at 200 revolutions per minute (max. bottle rotation $100 \mathrm{rpm}$ ) (Fig. 2). 


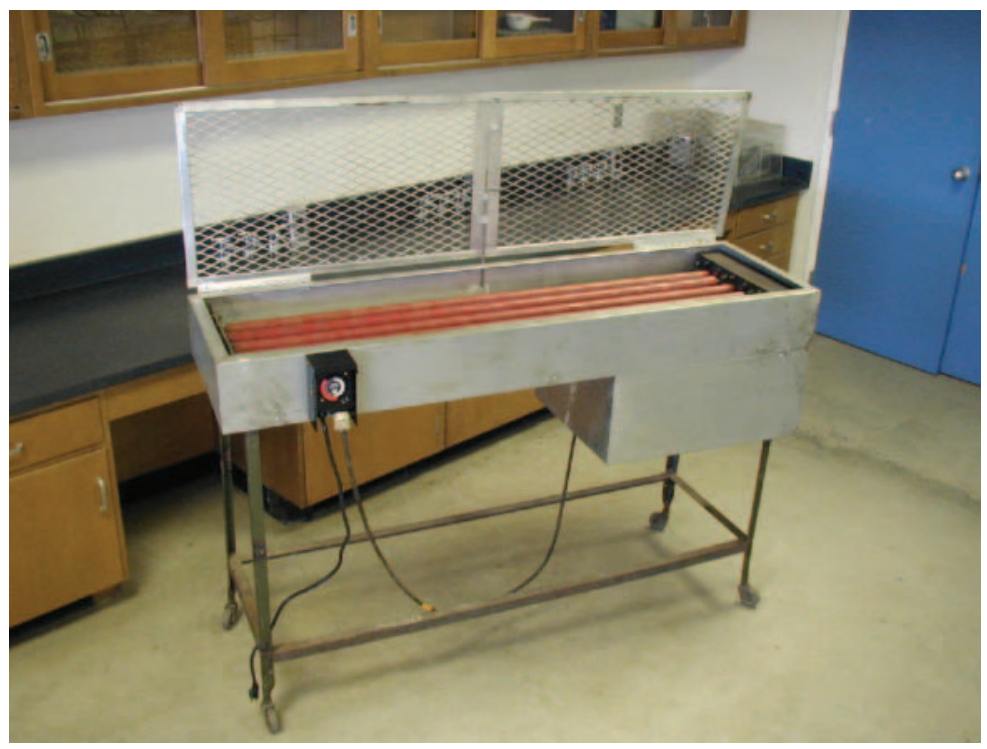

Figure 1. Roller mill. (View this art in color at www.dekker.com.)

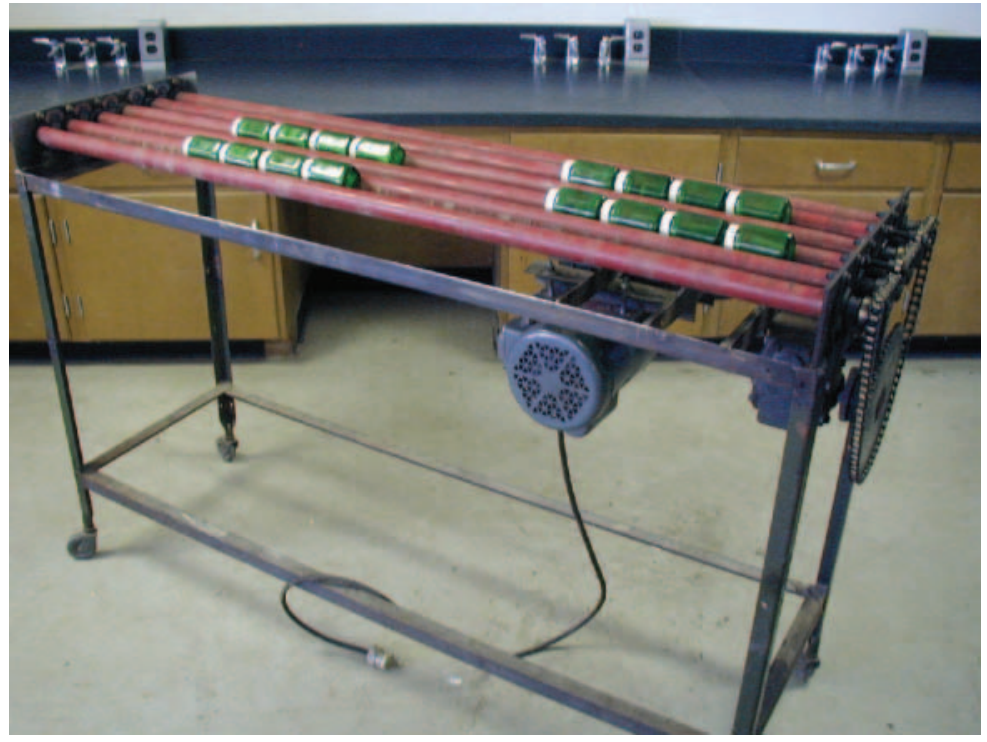

Figure 2. Roller mill showing six rotating rods with square bottles (safety guard has been removed to show drive mechanism). (View this art in color at www.dekker.com.) 


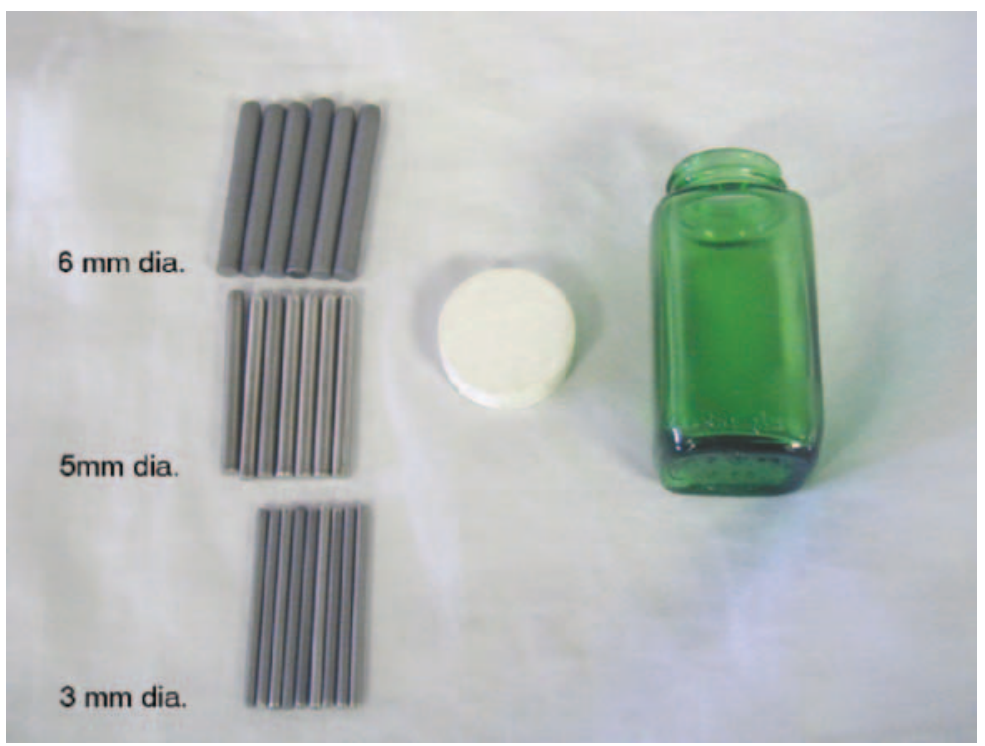

Figure 3. Square bottles and rods. (View this art in color at www.dekker.com.)

Instead of milling samples in the traditional round glass bottles on the roller mechanism, the square bottles $(7.0-\mathrm{cm}$ tall, $4.0-\mathrm{cm}$ sides, $3-\mathrm{mm}$ thickness) (Fig. 3) were used to increase the hammering action. Four 3-mm diameter stainless steel rods (SAE No. 30304) (Fig. 3) near the length of each bottle $(\sim 5.5 \mathrm{~cm})$ were placed into each, along with the oven dried (plant $55^{\circ} \mathrm{C}$ and soil $70^{\circ} \mathrm{C}$ ) sample. Sample size for soil, plant stems and leaves, and grain was approximately $2.5,0.3$, and $1.5 \mathrm{~g}$, respectively. A milling time of $16 \mathrm{~h}$ was used for all samples. Soil samples processed with the roller mill were compared with those from a ball mill (Spex ${ }^{\mathrm{a}}$ model 8000, Spex Industries, Edison, NJ) and with a soil grinder-blender (M.G. Johnston ${ }^{\text {a }}$ Industries, Inc., Minnetonka, MN). Particle size distribution of a Sharpsburg silty clay loam soil after being processed by each method is given in Table 1. Plant samples processed with the roller mill were compared with those processed with a ball mill (Spex ${ }^{\mathrm{a}}$ model 8000, Spex Industries, Edison, NJ). Plant samples were processed prior to roller milling and ball milling (Spex ${ }^{\mathrm{a}}$ model 8000, Spex Industries, Edison, NJ) with a Wiley ${ }^{\mathrm{a}}$ mill (20-mesh sieve) for leaf and stem materials, a Stein ${ }^{\mathrm{a}}$ mill for corn grain, and a Buhler ${ }^{\mathrm{a}}$ mill for flour.

Chemical analyses for total $\mathrm{N}$, total $\mathrm{C}$, and ${ }^{15} \mathrm{~N}$ were performed using a Carlo Erba ${ }^{a}$ model NA 1500 analyzer that was coupled to a Europa 
Table 1. Particle size distribution of a Sharpsburg silty clay loam soil after processing with three devices. ${ }^{\text {a }}$

\begin{tabular}{lccc}
\hline & \multicolumn{3}{c}{ Percent of sample by category } \\
\cline { 2 - 4 } Method & $<100$ mesh & $50-100$ mesh & $>50$ mesh \\
\hline Johnston grinder & 52.2 & 12.9 & 34.9 \\
Spex mill (3 min) & 82.5 & 7.1 & 10.4 \\
Roller mill (16 h) & 99.2 & 0.8 & 0.0 \\
\hline
\end{tabular}

${ }^{\text {a }}$ Spex mill and roller mill samples, were initially processed using the Johnston grinder.

Scientific ${ }^{\mathrm{a}}$ stable isotope mass spectrometer. ${ }^{[8]}$ Total $\mathrm{C}$ and total $\mathrm{N}$ data were derived from the thermal conductivity detector of the Carlo Erba ${ }^{\mathrm{a}}$ analyzer while all ${ }^{15} \mathrm{~N}$ data originated with the mass spectrometer. Ten subsamples of each sample type were used for each type of sample preparation.

\section{RESULTS AND DISCUSSION}

Substituting square glass bottles for round bottles on the rotating rollers of the milling apparatus resulted in the contents of the bottles rapidly falling $\sim 3 \mathrm{~mm}$ as the bottles rotate. The systematic but irregular rotation of the square bottles accentuates the tumbling action of the small stainless steel rods within each bottle. The square bottles reduced milling time and provided a smaller average particle size for hard to grind materials. In the case of a silty clay loam soil, essentially the entire sample passed through a 100-mesh sieve with the roller mill, compared to only $83 \%$ for the Spex ${ }^{\mathrm{a}}$ mill processed sample (Table 1).

Benefits of a more homogeneous sample are frequently reflected in greater analytical precision, especially for materials that are hard to grind or samples that tend to segregate during handling. Both the ball mill and roller mill effectively increased precision of total $\mathrm{N}$ determination in plant materials and for both total $\mathrm{C}$ and total $\mathrm{N}$ in soils (Table 2). Individual soil and plant sample data for the roller and ball mills showed good correlation for total C, total N, and ${ }^{15} \mathrm{~N}$ (Fig. 4). The slopes were 1.0. In addition, the linear coefficients of determination were $r^{2}=1.0$ which indicated agreement between methods. Although ball milled flour appeared to have a slight gray color, and the roller-milled flour did not, few differences were seen from additional milling of the flour (white bread flour) because it was 
Table 2. Total $\mathrm{N}$, total $\mathrm{C}$, and ${ }^{15} \mathrm{~N}$ concentrations for various materials processed with grinding devices. ${ }^{\mathrm{a}}$

\begin{tabular}{lccc}
\hline Material/method & $\begin{array}{c}\mathrm{C}^{\mathrm{b}} \\
(\%)\end{array}$ & $\begin{array}{c}\mathrm{N}^{\mathrm{b}} \\
(\%)\end{array}$ & $\begin{array}{c}{ }^{15} \mathrm{~N}^{\mathrm{b}} \\
(\mathrm{atm} . \%)\end{array}$ \\
\hline Corn grain & & & \\
$\quad$ Roller mill & $42.81(0.44)^{\mathrm{c}}$ & $1.310(1.01)$ & $0.4852(0.36)$ \\
$\quad$ Spex mill & $42.80(1.08)$ & $1.311(1.15)$ & $0.4864(0.63)$ \\
$\quad$ Stein mill & $42.75(0.72)$ & $1.298(4.62)$ & $0.4861(5.35)$ \\
Corn stover & & & \\
$\quad$ Roller mill & $42.82(0.96)$ & $0.582(4.64)$ & $1.0378(0.58)$ \\
$\quad$ Spex mill & $43.19(0.64)$ & $0.555(6.76)$ & $1.0266(1.43)$ \\
$\quad$ Wiley mill & $43.38(0.91)$ & $0.552(14.98)$ & $1.0300(3.12)$ \\
Flour & & & \\
$\quad$ Roller mill & $43.69(1.63)$ & $2.295(1.50)$ & $0.3737(0.10)$ \\
$\quad$ Spex mill & $43.33(1.75)$ & $2.272(0.97)$ & $0.3749(0.09)$ \\
$\quad$ Buhler mill & $43.06(1.97)$ & $2.300(1.72)$ & $0.3746(0.10)$ \\
Soil (Sharpsburg) & & & \\
$\quad$ Roller mill & $1.584(1.47)$ & $0.161(1.36)$ & $0.3754(0.50)$ \\
$\quad$ Spex mill & $1.711(1.78)$ & $0.173(1.60)$ & $0.3764(0.61)$ \\
$\quad$ Johnston grinder & $1.759(4.78)$ & $0.183(4.24)$ & $0.3777(0.40)$ \\
\hline
\end{tabular}

${ }^{a}$ Corn grain, corn stover, flour, and soil were initially processed using a Stein mill, Wiley mill, Buhler mill, and a Johnston grinder respectively. ${ }^{b}$ Mean values of 10 consecutively injected soil and plant samples.

${ }^{c}$ Numbers in parentheses are coefficients of variation $(\%)$.

already quite homogeneous. Grinding and homogenizing soils with the Spex $^{\mathrm{a}}$ mill resulted in an average $8 \%$ increase in total $\mathrm{C}$ compared to the roller mill, which is attributed to abrasion of the steel grinding vessel and ball bearings (Table 2). This hypothesis was verified by reprocessing a series of soil samples through the $\operatorname{Spex}^{\mathrm{a}}$ mill which resulted in an average $3.5 \%$ greater total $\mathrm{C}$ content after the second milling process. Mozafar et al. ${ }^{[7]}$ also found abrasion of metal elements from the mill parts influenced analytical concentrations in plant materials, but acknowledged that soil particles, dust, etc. could also contaminate samples. The more gentle and prolonged grinding in the roller mill would be less likely to result in increased total $\mathrm{C}$ content of the sample because the metal rods were made of stainless steel. The higher total $\mathrm{C}$ concentration in the composite soil sample processed with the Johnston ${ }^{\mathrm{a}}$ grinder-blender (Table 2) is attributed to larger particles/aggregates passing through the apparatus that were probably more highly aggregated by organic components and resistant to crushing. This hypothesis is supported by the slightly higher 

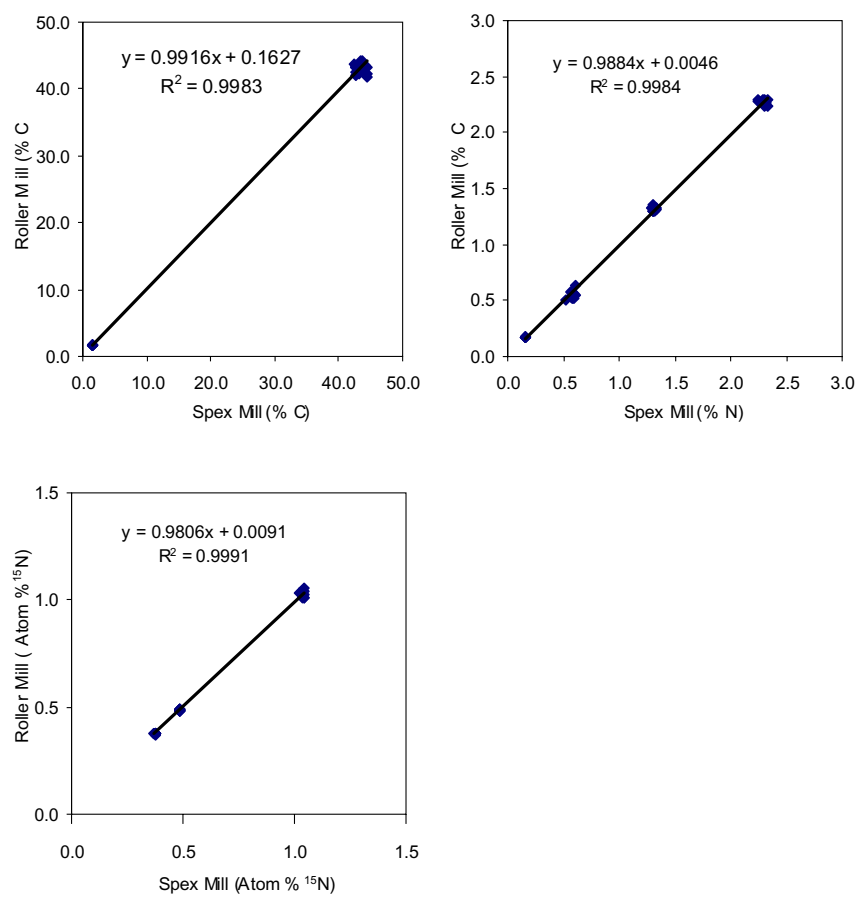

Figure 4. Comparison of soil and plant sample processing using a roller mill grinder for total carbon, total nitrogen, and isotopic nitrogen analysis with a Spex mill grinder.

$\mathrm{C}: \mathrm{N}$ for the $\mathrm{Spex}^{\mathrm{a}}$ mill $(9.89: 1)$ compared to the composite material that passed through the Johnston ${ }^{\mathrm{a}}$ grinder-blender (9.61:1).

\section{CONCLUSIONS}

Performance of the roller-mill apparatus with square glass bottles was at least equivalent to the precision and accuracy resulting from samples prepared with the $\operatorname{Spex}^{\mathrm{a}}$ mill. Aggressive milling operations, as with the Spex ${ }^{a}$ mill, resulted in higher C concentrations of soil samples because of the abrasion of the steel-grinding device. Plant material with high oil content prevented the use of either method. Since 1992 the Soil and Water Conservation Research Unit in Lincoln, Nebraska has processed a combination of 5000 soil and plant samples each year using the roller mill. Equipment repair consisted of 3 belts, 2 roller chains, 
9 bearings and 1 electric motor at a cost of less than $\$ 300$. Breakage of square bottles was $<1 \%$ per year. The low labor requirement and large number of samples that can be processed at one time make the roller mill with square bottles a viable improvement for processing and homogenizing plant and soil samples. Use of square grinding bottles may also have application for conveyor-belt grinding devices.

\section{ACKNOWLEDGMENTS}

The authors would like to thank Meggen Hackwith for her work on the figures in this article and past staff of the USDA-ARS Soil and Water Conservation Research Unit in Lincoln, Nebraska, for their contributions in preparation of this article.

\section{REFERENCES}

1. Bremmer, J.M.; Mulvaney, C.S. Total: nitrogen. In Methods of Soil Analysis, Part 2, 2nd Ed.; Page, A.L., Miller, R.H., Keeney, D.R., Eds.; American Society of Agronomy: Madison, WI, 1982; 595-624.

2. Horneck, D.A.; Miller, R.O. Determination of total nitrogen in plant tissue. Handbook of Reference Methods for Plant Analysis; CRC Press: BocaRaton, FL, 1998; 75-83.

3. Nelson, D.W.; Sommers, L.E. Total carbon, organic carbon, and organic matter. In Methods of Soil Analysis, Part 2, 2nd Ed.; Page, A.L., Miller, R.H., Keeney, D.R., Eds.; American Society of Agronomy: Madison, WI, 1982; 539-577.

4. Smith, J.L.; Myung, H.U. Rapid procedures for preparing soil and $\mathrm{KCl}$ extracts for $15 \mathrm{~N}$ analysis. Commun. Soil Sci. Plant Anal. 1990, 21, 2173-2179.

5. Kelley, K.R. Conveyor-belt apparatus for fine grinding of soil and plant materials. Soil Sci. Soc. Am. J. 1994, 58, 144-146.

6. Houba, V.J.G.; Chardon, W.J.; Roelse, K. Influence of grinding of soil on apparent chemical composition. Commun. Soil Sci. Plant Anal. 1993, 24, 1591-1602.

7. Mozafar, A.; Oertli, J.J.; Ambuehl, B. Particle size and element concentration in ground plant material. Commun. Soil Sci. Plant Anal. 1990, 21, 1619-1632.

8. Schepers, J.S.; Francis, D.D.; Thompson, M.T. Simultaneous determination of total $\mathrm{C}$, total $\mathrm{N}$, and $15 \mathrm{~N}$ on soil and plant material. Commun. Soil Sci. Plant Anal. 1989, 20, 949-959. 